ARTICLE HISTORY: Received: October 12, 2021 Accepted: December 06, 2021 Published: December 13, 2021

\title{
BIOLOGICAL PROPERTIES OF SELENIUM
}

\author{
Kasharnaya Olga Vladislavovna ${ }^{1}$, Salimzade Emil Aflatun oglu ${ }^{1}$, \\ Ermilova Tatiana Sergeevna ${ }^{1}$, Samburova Margarita Aleksandrovna ${ }^{2}$ \\ ${ }^{1}$ Astrakhan State University, Astrakhan \\ ${ }^{2}$ BIOS LLC, Moscow
}

\begin{abstract}
The article describes the involvement of selenium in the biophysical, metabolic, and energetic processes of humans and animals, its biological functions in the living systems. The authors mention the importance of the opening and further study of the microelement for living organisms and their protection from pathology and viruses. The content of the microelement in food products and plants are discussed as well as the necessity in an increase in agricultural crops and farm animal production efficiency.

Keywords: selenium, microelement, biological properties of selenium, antioxidant protection, anticarcinogenic factor.
\end{abstract}

\section{INTRODUCTION}

Selenium is one of the most important microelements (mass fraction in a human organism is 10-5-10-7\%) that can maintain various biological functions in living organisms. It influences protein metabolism, in particular, sulfurcontaining amino acids, hormones, and lipid structures. This microelement is one of 30 essential compounds in the organisms of higher animals and is included in the structure of molecules of various enzymatic systems [1,2]. Selenium is an essential microelement that was classified as toxic until recently. In XIII century, Marco Polo wrote about the poisoning of horses that were eating plants in Tibet. This provided a reason for the study of toxic elements and the associated specific diseases. Even though $\mathrm{Se}$ is one of the most toxic elements, it exerts some biochemical functions that determine the activity of some most important enzymes [3]. Selenium is included in the group of seven elements (Fe, $\mathrm{Ca}, \mathrm{Mg}, \mathrm{I}, \mathrm{Se}, \mathrm{Zn}$, and $\mathrm{Cu}$ ) that are deficient in the population of our planet.

Selenium was opened in 1817 in the rock chips of lead chambers of a sulfate plant in Gripsholm by a Swedish chemist Berzelius. Its average content in the Earth's crust is $5 \times 10-6 \%(0.05 \mathrm{mg} / \mathrm{kg})$. Se content in plants is $0.03-0.2$ $\mathrm{mg} / \mathrm{kg}$ of the dry matter, in organs and tissues of terrestrial animals $-0.3-1.7 \mathrm{mg} / \mathrm{kg}$. Se was acknowledged as an essential element in 1957 [4].

A significant contribution to the study of the biological role of Se was made by the German scientist K. Schwartz. Experiments with rats that received casein treated with $0.1 \mathrm{M}$ solution of sodium hydroxide, necrotic degeneration of the liver developed both in animals that received feed with normal content of vitamin E and sulfur-containing amino acids. The developed disease suggested an additional factor that contributed to the disease development, which was a substance removed by alkaline hydrolysis [5].

Further studies showed that Se and vitamin E deficiency in a diet causes the development of some pathologies in farm animals $[6,7]$.

\section{SELENIUM ROLE IN LIVING ORGANISMS}

The peculiarity of Se metabolism is in its absorption in an animal organism throughout the digestive tract. The ingestion of Se reaches $70-80 \%$. In ruminant animals, it is primarily absorbed by the mucous membrane of the forestomach. In horses, it is absorbed in the blind gut. It is transported in the organism as a part of a compound with $\alpha$ and $\beta$-globulins of the blood. Around $79 \%$ of Se is absorbed by erythrocytes and the rest is deposited by the cells of the kidneys, liver, and other tissues. Depending on the composition of an animal's diet, it is excreted with urine and feces. The multiplicity of the accumulation of Se in soft tissues is equal to 87, and the biological period of elimination half-life is 50-60 days [8].

Se replaces sulfur in cysteine and methionine forming selenium-containing amino acids selenocysteine and selenomethionine. These amino acids are more biologically active and exert better radioprotective properties than cysteine and methionine. They decrease the level of free radicals that lead to the accumulation of products of oxidation that induce oxidative destruction of cellular membranes $[9,10]$. Thus selenium is an element that exerts numerous protective functions that enhance the immune protection of the organism. High levels of Se contribute to the fight against cancer. The element can protect the organism from poisoning with mercury, cadmium, arsenic, thallium, and vanadium.

In 1980, the WHO acknowledged Se as an essential element of nutrition. According to the accepted international norms, its optimal content is $100-300 \mu \mathrm{g} / \mathrm{kg}$ of dry matter of food or animal feed [1]. A daily requirement of Se in a human organism is 80-200 $\mu \mathrm{g}$. Its concentration in an organism depends on age. The highest concentrations of this element are revealed in the brain, kidneys, liver, endocrine glands, and other structures of an organism. In the blood, its concentration is $0.74-2.97 \mu \mathrm{mol} / \mathrm{L}$. Non-organic compounds of Se are ingested worse than organic. From 55 to $80 \%$ of 
the consumed microelement is primarily absorbed in the duodenum. Se can be absorbed via the lungs and skin. Lipoproteides of the human blood plasma contain around $6 \%$ of Se from its total content in the plasma.

$\mathrm{Se}$ is transported in the organism by selenoprotein P. Selenium is excreted from the organism via the kidneys, with feces and exhaled air. It is excreted with urine as methylated Se and via the lungs - as dimethyl selenide.

It is known that selenium-containing proteins that are found in vertebrates contain only one selenium-containing amino acid - selenocysteine. Se that is present in the composition of selenite and selenides is included in the amino acid serine that serves as the only direct precursor of selenocysteine, i.e. an organism can synthesize selenocysteine using only a carbon skeleton of serine and mineral selenium [1]. The microelement in the bivalent organic form is presented as selenocysteine (Se-Cys) in animal-derived products, and selenomethionine in plant-derived products (Se-Met) [11, 12]. In plants, Se can affect the processes of growth, photosynthesis, cold- resistance, drought resistance, and productivity of crops. Se is absorbed inside plants with sulfate transmitters and is ingested due to sulfur [13].

Selenocysteine and selenomethionine are more preferable for the organism because of high availability, which is 95-98\% in an organic form and $10 \%$ in a non-organic form. An organism receives Se with consumed food.

In the human genome, 35 selenoproteins are transcribed that are directly associated with redox processes. Selenoproteins are divided into proteins presented by nonspecific inclusion of selenium, specific selenium-binding proteins, and specific selenocyteine-containing selenoproteins. The main selenium-containing enzymes include five glutathione peroxidases (GPO): classic GPO 1, gastrointestinal GPO 2, plasma GPO 3, phospholipid hydroperoxide GPO 4, and nuclear GPO 5 off spermatozoids; thioredoxin reductase (TR) selenophosphate synthase, and 2 deiodinases. Glutadionperoxidases and thioredoxin reductases reduce hydroperoxide protecting an organism from oxidative stress when reactive oxygen $(\mathrm{OH} \bullet, \mathrm{O} 2$-) and nitrogen (NO•) intermediates are accumulated. Their production is regulated by vascular $\mathrm{NAD}(\mathrm{P}) \mathrm{H}$ oxidases and endothelial nitroxide synthase. Their metabolism and physiological functions are coordinated by GPO and thioredoxin-TR systems. Endothelial selenoproteins regulate vascular tonus maintaining O2/NO balance, cellular adhesion, apoptosis, synthesis of eicosanoids by cyclic and lipoxygenases, and regulating inflammation and atherogenesis. Numerous studies show the role of Se ions and compounds as antioxidant agents [14, $15,16]$.

The ratio of the activity of peroxide oxidation of lipids (POL) and components of the system of antioxidant protection, which includes selenocysteine-containing GPO, significantly affects the pathogenesis of reproductive system diseases that often develop because of oxidative stress. Selenium compounds exert a positive effect on the endocrine function of the fetoplacental system, synthesis, and metabolism of reproductive hormones providing high contractive activity of the uterine and prevention of post-partum complications. It also maintains the activity of an enzymatic link of the system of antioxidant protection being a part of an antioxidant enzyme molecule [17, 18, 19, 20]. Glutadionperoxidase and thioredoxin reductase reduce hydroperoxides protecting cellular structures from oxidative damage and accumulation of reactive oxygen intermediates (ROI) [21].

Selenium-containing feed supplements in pregnant cows maintain the processes of lipid oxidation that are shown $[19,22]$ to become more active in the prenatal period. The study that included red-and-white cow breed showed that the indication of "Selemag" (Vitamin E + sodium selenite) to cows from one of the test groups (at the dose of $100 \mu \mathrm{g} / \mathrm{kg}$ of living mass one month before the delivery) led to an increase in the activity of Malone aldehyde by $17.3 \%$ in comparison with the reference. In the group that received "Seledant" (organic selenium) at the dose of $10 \mu \mathrm{g} / \mathrm{kg}$ of living mass one month before the delivery, it led to an increase in the activity of Malone dialdehyde by $8 \%$. In the control group, the activity of Malone dialdehyde increased by $34.7 \%$. The concertation of the main selenium-containing enzyme of AOP (glutathione peroxidase) decreased by $8.9-11 \%$ in comparison with the reference. At the same time, its parameters increased by $1.34-1.39 \%$ in comparison with the control group (at $\mathrm{P}<0.01$ ) [22]. Thus, the application of organic and non-organic selenium-containing drugs in pregnant cows in the prenatal period stabilizes free-radical oxidation by maintaining the balance of production and utilization of ROI due to the provision of an enzymatic link of the AOP system.

The involvement of Se in the biophysical, metabolic, and energetic processes of the human and animal organism has been proved by numerous study results and is still being studied.

The content of the microelement in plants depends on agrochemical soil properties, weather conditions, phase of development, and biological peculiarities of plants. In plants, Se is found in non-organic forms presented by selenates and selenites and organic forms [23]. The mean content of Se in plants is $01-10 \mathrm{mg} / \mathrm{kg}$ [24]. A deficit of Se occurs when its levels fall below $0.05 \mathrm{mg} / \mathrm{kg}$. According to Cabata-Pendias, normal concentration of Se in the leaves are 0.01-2.0 $\mathrm{mg} / \mathrm{kg}$ and toxic $-5-30 \mathrm{mg} / \mathrm{kg}$ [25]. The content of Se in plants is $10-1100 \mu \mathrm{g} / \mathrm{kg}$ of dry matter $[26,27,28]$.

The products with high content of Se include Brazil nut $(1530 \mu \mathrm{g} / 100 \mathrm{~g})$ and sunflower seeds $(79 \mu \mathrm{g} / 100 \mathrm{~g})$. Selenium is found in sesame, flax, and chia seeds. The content of Se in chicken eggs is $31.7 \mu \mathrm{g}$, in cottage cheese - from 10 to $30 \mu \mathrm{g} / 100 \mathrm{~g}$ depending on the origin. Beans, like other products containing Se, is a potent diuretic, dilates vessels, improves metabolism, and stabilizes the levels of glucose in the blood decreasing the hypoglycemic index in people with diabetes. A hundred grams of beans contain $24.9 \mu \mathrm{g}$ of Se. The content of Se in $100 \mathrm{~g}$ of garlic is $14.2 \mu \mathrm{g}$. A hundred grams of fish and seafood contain $154 \mu \mathrm{g}$ of Se. Boiled calamaries contain $130 \mu \mathrm{g}$ of Se, tinned tuna $-90 \mu \mathrm{g} / 100 \mathrm{~g}$. Different types of meat contain from 10 to $100 \mu \mathrm{g} / 100 \mathrm{~g}$ of Se. Fried pork contains $21 \mu \mathrm{g}$ of Se and chicken breast 
(without skin) - $16 \mu \mathrm{g}$. Fine-ground barley cereal contains $23 \mu \mathrm{g}$ of Se and wheat cereal $-19 \mu \mathrm{g}$. Rye bread contains $36.6 \mu \mathrm{g}$ of Se and whole-grain bread from wheat flour $-40 \mu \mathrm{g} / 100 \mathrm{~g}$.

In native grasses, the content of Se is $2-174 \mu \mathrm{g} / \mathrm{kg}$ [29]; in perennial grasses $-64-108 \mu \mathrm{g} / \mathrm{kg}$ [26]; in wheat -10 $421 \mu \mathrm{g} / \mathrm{kg}$; rye $-5-52 \mu \mathrm{g} / \mathrm{kg}$; barley $-4-200 \mu \mathrm{g} / \mathrm{kg}$; oats $5-248 \mu \mathrm{g} / \mathrm{kg}$. The content of Se in crops is affected by the level of the microelement in soils [26, 27, 28, 29, 30]. Intensive application of phosphorus and other fertilizers and soil poisoning with heavy metals can lead to Se deficiency in soils. To increase the productivity of crops, seleniumcontaining fertilizers should be applied [31].

The deficiency of vitamin $\mathrm{E}$ and selenium in animal feed leads to a delay in animal growth, degenerative and dystrophic changes in such tissues as the myocardium, skeletal muscles, neural cells, bone tissue structures, liver, skin, and hair. It also provokes pathologies in other organs and tissues and decreases reproductive function [32]. Thus, in 75\% of newly-calved cows, cases of endometrial pathology are observed. They have prolonged time of uterine involution, later oestrus, retention of placenta, and frequent miscarriages. Se can reduce the rate of mutations, exerts anti-teratogenic and radioprotective effects, stimulate antioxidant protection normalizers nucleic acids, proteins, and eicosanoid metabolism, and regulate the function of the thyroid and pancreas. Selenium affects hormones and neurotransmitters [33, 34].

Low Se levels can be associated with an increase in the spread and virulence of viruses, and peculiarities of some disease development associated with viral infections, for example, herpetic angina [35, 36, 37]. Lately, Se attracts the attention of medical specialists because of the spread of the novel coronavirus infection. It was established that deficiency of Se and selenoproteins is associated with an increase in the morbidity and lethality rates from COVID-19. German scientists revealed that the average level of Se in patients who died from COVID-19 was decreased in comparison with recovered patients $(40.8 \pm 8.1$ vs $53.3 \pm 16.2 \mu \Pi / \mathrm{L})$ as well as the level of selenoprotein $\mathrm{P}(2.1 \pm 0.9$ vs $3.3 \pm 1.3 \mathrm{mg} / \mathrm{L}$ ). Sodium selenite can oxidize thiol-containing groups in the disulfide-isomerase of a viral protein reducing viral permeability capacity via the cell membrane $[38,39]$.

\section{CONCLUSION}

Selenium exerts a positive effect on the quality of life, increases resistance to oxidative stress, reduced the rate of development of age-related diseases, i.e. can be classified as geroprotector. Se is an anti-carcinogenic factor. Deficit of selenium reduces immunity, contributes to the development of atherosclerosis, cataract, growth retention, and leads to the development of pathology of the surfactant lung system and reproductive system pathology. It is suggested that there is an association between low selenium levels and an increase in the spread of viruses, their virulence, and peculiarities of the disease development. Selenium deficiency leads to a decrease in the rate of migration of neutrophils from the blood to organism tissues, which is associated with an increase in neutrophil adhesion on epithelial cells. Thus, there is an association between Se consumption and pathological conditions. For this reason, it is important to optimize the daily consumption of this element in a person's nutrition.

The possibility to use selenium in the prevention of COVID-19 attracts researchers' interest because it was established that selenium and selenoprotein deficiency was associated with an increase in the morbidity and lethality rate from COVID-19. The capacity of sodium selenite to oxidize thiol-containing groups in the disulfide-isomerase requires further studies as well as other possible effects of this microelement on the development of diseases.

\section{REFERENCES}

1. Galochkin V.A, Galochkina V.P. Organic and mineral forms of selenium, their metabolism, bioavailability and role in the body. Sel'skokhozyaystvennaya biologiya. 2011. Vol. 46. No. 4. pp. 3-15. (In Russian).

2. Safonov V.A. Comparison of LPO-AOS Indices and Biochemical Composition of Animal Blood in Biogeochemical Provinces with Different Levels of Selenium. Biological Trace Element Research. 2021. pp. 1-7.

3. Krieger P.O., Mokhova E.V. The biological role of selenium in the nutrition of farm animals and poultry. Chemistry and Life. Collection of articles of the XIX International Scientific and Practical Student Conference, 2020. pp. 58-62.

4. Gilinskaya L.G., Grigorieva T.N., Razvorotneva L.I., Trofimova L.B. Composition and physicochemical properties of natural blue clays. Chemistry for sustainable development. 2008. Vol. 16. No. 2. pp. 147-157.

5. Schwarz K., Foltz C. Selenium as an integral part of factor 3 against necrotic dietary liver degeneration. J. Am. Chem. Soc. 1957. Vol. 79. pp. 3292-3293.

6. Prokhorova Yu.V., Gavrikov A.V. The influence of selenium on the body of poultry. Ptitsevodstvo. 2015. No. 10. pp. 9-11. (In Russian)

7. Chernitskiy A., Shabunin S., Kuchmenko T., Safonov V. On-farm diagnosis of latent respiratory failure in calves. Turkish Journal of Veterinary and Animal Sciences. 2019. Vol. 43. No. 6. pp. 707-715.

8. Ganther H.E. Selenium metabolism and function in man and animals. De Gruyter. 2021. pp. 1-24.

9. Golubkina N.A. Selenium content in wheat and rye flour of Russia, CIS and Baltic countries. Voprosy pitaniya. 1997. No. 3. pp. 17-20. (In Russian). 
10. Polkovnichenko P., Vorobiev D., Vorobiev V., Safonov V. Comprehensive diagnosis of selenium and iodine deficiencies in golden manchurian quails and gray-speckled guinea fowls risen in the astrakhan region. Advances in Animal and Veterinary Sciences. 2021. No. 9(6). pp. 904-912.

11. Amini P., Kolivand S., Saffar. H., Rezapoor S., Motevaseli E., Najafi M., ... Musa A.E. Protective effect of Selenium-L-methionine on radiation-induced acute pneumonitis and lung fibrosis in rat. Current clinical pharmacology. 2019. No. 14(2). pp. 157-164.

12. Mousaie A., Valizadeh R., Chamsaz M. Selenium-methionine and chromium-methionine supplementation of sheep around parturition: impacts on dam and offspring performance. Archives of animal nutrition. 2017. No. 71(2). pp. 134-149.

13. Dumont E., Vanhaecke F., Cornelus R. Selenium speciation from food source to metabolites: a critical review. Anal. Bioanal. Chem. 2006. No. 385. pp. 1304-1323.

14. Xie X., Chen M., Zhu A. Identification and characterization of two selenium-dependent glutathione peroxidase 1 isoforms from Larimichthys crocea. Fish \& shellfish immunology. 2017. Vol. 71. pp. 411-422.

15. Salman M. Effects of different levels of organic selenium supplementation on fattening performance, carcass characteristics and blood GSH-Px activity in lambs. Rev. med. Vet (France). 2009. Vol. 160. No. 5. pp. $258-264$.

16. Maldonado G., Nava G., Plancarte A. Two glutathione transferase isoforms isolated from juvenile cysts of Taenia crassiceps: identification, purification and characterization. Journal of helminthology. 2018. Vol. 92. №. 6. pp. 687-695.

17. Ventsova I., Safonov V. The role of oxidative stress during pregnancy on obstetric pathology development in high-yielding dairy cows. American Journal of Animal and Veterinary Sciences. 2021. No. 16 (1). pp. 7-14.

18. Troshina E.A., Senyushkina E.S., Terekhova M.A. The role of selenium in the pathogenesis of thyroid diseases. Klinicheskaya i eksperimental'naya tireoidologiya. 2018. Vol. 14. No. 4. pp. 92-205. (In Russian).

19. Postrash I.Yu., Soboleva Yu.G., Zasinets S.V., Postrash Ya.V. The state of lipid peroxidation in pregnant cows. Uchenyye zapiski uchrezhdeniya obrazovaniya Vitebskaya ordena Znak pocheta gosudarstvennoy akademii veterinarnoy meditsiny. Vol. 44, Issue 2. pp. 115-117. (In Russian).

20. Galochkin V.A., Galochkina V.P. Metabolic transformations of selenium and the biological function of selenopyran. Problemy biologii produktivnykh zhivotnykh. 2008. No. 4. pp. 3-20. (In Russian).

21. Anuryeva T.M., Stanevich L.M., Anuryev A.M., Filippova G.T. The biological role of selenium. Innovatsionnyye tekhnologii v farmatsii. 2019. Issue 6. pp. 500-505. (In Russian).

22. Safonov V.A. Metabolic profile of high productive cows during pregnancy and barrenness. Sel'skokhozyaystvennaya biologiya. 2008. Vol. 43. No. 4. pp. 64-67. (In Russian).

23. Seregina I.I., Nilovskaya N.T. The biological role of selenium in plants. Agrohimiya. 2002. No. 10. pp. $76-85$. (In Russian).

24. Sheujen A.Kh. Agrobiogeochemistry. 2-ye izd., pererab. i dop. Krasnodar: Izd-vo KubGAU, 2010. 877p. (In Russian).

25. Cabata - Pendias A. Trase Elements in Soilsand Plant. FL: CrsPress, FL, 2010. 548 p.

26. Golubkina N.A., Papazyan T.T. Selenium in nutrition: plant, animal, man. M.: Pechatniy gorod, 2006.255 p. (In Russian). (In Russian).

27. Sindireva A. Criteria and parameters of the action of microelements in the soil - plant - animal system. Author. dis. Dr. Biol. sciences. Tyumen, 2012. 32 p.

28. Shubina O.I., Kashin V.K. The influence of selenium on spring wheat in the conditions of a selenium-deficient biogeochemical province. Agrohimiya. 2012. No. 5. pp. 45-51. (In Russian).

29. Aristarkhov A.N. Optimization of the polyelement composition in the agroecosystems of Russia. Ecological and agrochemical assessment of the state, deficit, reserves, methods and means of management. Moscow: Izdatelskiy dom VNIIA, 2019. 832 p. (In Russian).

30. Puccinelli M., Malorgio F., Pezzarossa B. Selenium enrichment of horticultural crops. Molecules. 2017. Vol. 22. No. 6. P. 933.

31. Pobilat A.E., Voloshin E.I. Features of the content of selenium in the soil-plant system. Vestnik Krasn. GAU. 2020. No. 11 (164). pp. 98-105. (In Russian).

32. Vorobyov V., Vorobyov D., Polkovnichenko P., Safonov V. Evaluation of hematological and metabolic parameters in small ruminants with trace elements deficiency under different biogeochemical conditions. Worlds Veterinary Journal. 2019. Vol 9. No. 4. pp. 311-316.

33. Galin P., Galyaveeva A., Bataev H., Safonov V. The role of micronutrients and vitamins in the prevention and remote treatment of heart failure. Revista Latinoamericana de Hipertension. 2020. Vol. 15. No. 1. pp. 26-32.

34. Rostami H., Mohammadi R., Asri-Rezaei S., Tehrani A.A. Evaluation of application of chitosan/nano selenium biodegradable film on full thickness excisional wound healing in rats. Iranian Journal of Veterinary Surgery. 2018. No. 13(1). pp. 14-22. 
35. Li Y., Lin Z., Guo M., Xia Y., Zhao M., Wang C., ... Zhu B. Inhibitory activity of selenium nanoparticles functionalized with oseltamivir on $\mathrm{H} 1 \mathrm{~N} 1$ influenza virus. International journal of nanomedicine. 2017. Vol. 12. P. 5733.

36. Shojadoost B., Taha-Abdelaziz K., Alkie T.N., Bekele-Yitbarek A., Barjesteh N., Laursen A., ... Sharif S. Supplemental dietary selenium enhances immune responses conferred by a vaccine against low pathogenicity avian influenza virus. Veterinary Immunology and Immunopathology. 2020. Vol. 227. P. 110089.

37. Shchigartsova V.V. Foodstuffs enrichment with selenium. Obrazovaniye i nauka bez granits: sotsial'nogumanitarnyye nauki. 2017. No. 6. pp. 249-252. (In Russian).

38. Kieliszek M., Lipinski B. Selenium supplementation in the prevention of coronavirus infections (COVID-19). Med Hypotheses. 2020. Vol. 143. art. 109878.

39. Jinsong Zh., Taylor E.W., Bennett K., Saad R., Rayman M.P. Association between regional selenium status and reported outcome of COVID-19 cases in China. Am J ClinNutr. 2020. Vol. 111. No. 6. pp. 1297-1299. 